The Geneva Papers on Risk and Insurance, 19 (No. 73, October 1994) 408-432

\title{
The Role for Paid Employment for Women and Men in their 50s and 60s in the UK Around the Millenium and Beyond*
}

\author{
by Chris Trinder**
}

\section{Abstract}

In this paper I examine recent trends in the employment of older men and women. I also forecast likely future scenarios given different assumptions. The analysis concentrates on the UK, but international comparisons and contrasts are noted. More than half the population of women aged 50-59 years in the UK are currently employees or selfemployed. With each successive cohort a larger proportion re-enter paid work, but they are remaining attached to the labour force for shorter periods. The overall employment-population rates for this age group and those in their 60 's has therefore been roughly constant for several decades. For men aged 55-64 years full-time employment was the norm in the UK throughout the 20th Century until the late 1970s. A sharp recession in the early 1980s altered this and it is now a 5:50 chance whether a 60 year old man will have a job. Despite a second long recession in the early 1990s the relative position for this age group has not worsened again to the same extent and slight increases in the employment-population ratios for some older age groups can be detected. In this paper I therefore examine whether the shake out of older males in recent decades may in the long run show up as a more temporary phenomenon. This paper is about older workers and their transition from paid employment to retirement, buth is should not be thought of as concerning a special group or merely the current cohort. We may all be in this position one day. Some of us are there now, but most of the rest of us will come up to it soon. Therefore we should not view the transitions as simply affecting someone else. The consequences of the policies that lead to what we observe now are what we will inherent when our turn comes. We need, therefore, to think of sensible policies for second agers as well as those about to retire if we are to make a lasting impression on the arcas of concern. It is on this wider context of present and future patterns of retirement that I concentrate in this paper.

* Paper given in session on "Work and Aging" (Fri-107) within the context of the overall conference theme "Incentives and values as foundations of social order" at the Fifth Annual International Conference of the Society for the Advancement of Socio-Economics, March 26-28 1993, at the Graduate Faculty, New School for Social Research, New York, USA.

** Research Director of the Public Finance Foundation, the research arm of the Chartered Institute of Public Finance and Accountancy. He is also the Director of the employment part of the Carnegie Inquiry into the Third Age and Special Advisor on state retirement pension age to the UK official Social Security Advisory Committee. 


\section{Introduction}

As recently as the late 1970 s, $85 \%$ of 55-64 year old men in the UK were economically active (see Table 1). 10 yers later and only two-thirds were so defined. This massive change from almost all being in full-time employment, to a third of them not being economically active at all, is a change which was unexpected as well as sudden. It had been the norm right the way through the century for people to work up until state retirement age. People had expected this and it had happened in almost all cases. Yet the shake-out in the recession in the UK at the end of the 1970s and early 1980s, the down-sizing and contractions of employment in particular companies, actually almost wiped out groups like the over $55 \mathrm{~s}$ altogether, as a category of employment (see Table 2).

The big employment changes of the late 1970s and early 1980s have particularly affected older workers. For example, never before has there been such a massive withdrawal from work by men who are below the conventional retirement age of 65 . Redundancy and unemployment have led to many leaving their.jobs earlier than they had anticipated: the spread of occupational pension schemes and the growth in private wealth holdings have, for others, opened up new opportunities for increased leisure. Over the same period more and more women have been re-entering the labour market after bringing up children and with many years of healthy active life ahead of them are looking for rewarding careers. So will future patterns of retirement be merely a continuation of past trends, a reversal of what has occurred in the past 13 years, or will some completely new patterns emerge?

Table 1:

Official mid-year estimates/projections of economic activity rates for males aged 55-64, Great Britain'

\begin{tabular}{|c|c|c|c|c|c|c|c|c|c|c|}
\hline \multicolumn{2}{|c|}{$\begin{array}{l}\text { Figures } \\
\text { given in } \\
\text { Employment } \\
\text { Gazette in }\end{array}$} & 1977 & 1980 & 1983 & 1986 & 1989 & 1990 & 1991 & 1992 & 2000 \\
\hline April & 1974 & 91.0 & 91.1 & 90.5 & 90.5 & 90.6 & & & & \\
\hline June & 1977 & 91.0 & 90.6 & & 89.9 & & & & & \\
\hline April & 1978 & 91.0 & 90.6 & 89.9 & 89.9 & 89.9 & & & & \\
\hline April & 1981 & 88.2 & 84.0 & 79.6 & 78.2 & & & & & \\
\hline Febr. & 1984 & 86.0 & 82.7 & 79.4 & 77.5 & 76.1 & & & & \\
\hline July & 1985 & 86.0 & 82.7 & 74.0 & 73.2 & 73.5 & & & & \\
\hline May & 1987 & 85.5 & 81.6 & 71.9 & 67.0 & 66.3 & & & & \\
\hline March & 1988 & & & 71.9 & 67.0 & 68.3 & & & & \\
\hline April & 1989 & & 81.6 & 71.9 & 67.6 & 71.6 & & & & \\
\hline April & 1990 & & & 71.9 & 67.6 & 67.4 & 67.4 & 67.4 & & \\
\hline May & 1991 & & & 71.9 & 67.6 & 67.4 & 68.0 & 67.2 & 67.2 & 67.0 \\
\hline April & 1992 & 85.5 & 81.6 & 71.9 & 67.6 & 67.3 & 68.0 & 68.3 & 67.5 & 66.5 \\
\hline
\end{tabular}

${ }^{1}$ Percentage economically active i. e. employed or unemployed.

Source: Calculated from Employment Gazettes, Various Issues, Department of Employment. 
Table 2:

Changing age structure of a declining company - 1974-87

\begin{tabular}{l|c|c|c|c}
\hline & Under 50 & $\begin{array}{c}50-55 \\
\text { percentage } \\
\%\end{array}$ & $55+$ & $\begin{array}{c}\text { Average age } \\
\%\end{array}$ \\
\hline 1974 & $\%$ & 16.8 & 23.0 & 43.6 \\
1977 & 60.2 & 15.1 & 19.1 & 41.1 \\
1980 & 65.8 & 11.9 & 16.3 & 39.4 \\
1983 & 71.8 & 11.4 & 8.6 & 37.9 \\
1986 & 80.0 & 6.7 & 1.6 & 35.7 \\
1987 & 91.7 & 4.9 & 1.0 & 35.2 \\
\hline
\end{tabular}

Source: Trinder, C. (1989), Employment after 55, NIESR.

\section{Current position}

There are currently three and a half million people of 55 and over in the UK workforce, making up about an eighth of the total. Of these, 2.1 million are men (one in seven of the male total) and 1.3 million are women (one in ten of the female total). The percentage distribution of jobs for men and women in this age group in each main sector of the economy and in the main types of occupation whithin those sectors is very similar to that for the work force as a whole. For example, the proportion of jobs in mental goods, engineering and vehicles is $13 \%$ for both third age men and all male workers.

Within the third age there are, however, important employment differences between those below and above the state pension age. The proportions in employment drop steeply after that age, so that for example in 1990 the proportion in employment of men aged 65-69 is less than half that for men aged 60-64. Among women there is a similar difference in the proportion in employment aged 60-64 compared to those in the 55-59 group. (See Figure 1 and 2). There is also a change in the skill-mix after state retirement age. The proportion of men in skilled manual jobs falls at age 65 and those over that age are more likely to be in non-manual or low-skill manual jobs. Among women above the state pension age of 60 , there are smaller proportions in managerial and professional jobs and higher proportions in semi-skilled or unskilled manual work. Over state-pension age there is also an increase in the proportion in "non standard jobs" - casual, part time and self employed. Labour force survey results from 1990 showed that one in three men aged 65-74 who were still working were doing so on a self-employed basis. Self-employment levels are particularly high in several of the industries where post-retirement age workers are concentrated (notably agriculture and private services). The self-employed are more likely than the employed to continue to work after state pension age because of the reduced influence of push factors (notably employer retirement policies) and pull factors (notably lack of occupational pensions). There is alsso a large increase in part-time working after state pension age. $67 \%$ of male workers over 65 are part-time, compared with only $6 \%$ in the $50-64$ groups. $75 \%$ 
of women workers over 60 are part-time but the contrast with the 50-59 group is less marked, because the employment pattern of women is different and part-time working in that group is already high $(52 \%)$.

\section{Historical trends}

The proportion of third age men in work has fallen rapidly in recent years. There have been falls both in the proportion actually employed (the "employment rate") and in those in the "economic activity rate" or seeking work. The most important falls have been among men aged 55-64. Since 1973 the employment rate for men aged 55-59 has fallen from $91 \%$ to about $68 \%$, and for men aged $60-64$ from $80 \%$ to $40 \%$. For the group as whole employment rates fell from $91 \%$ in 1970 to $68 \%$ in 1985 , a drop of $25 \%$. There has also been a decline in the economic activity rates of men over state pension age, but whereas for those below that age most of the decline took place after 1980, for those above it most of the decline took place earlier. The economic activity rate of 65-69 year old men which had fallen from $30 \%$ in 1971 to $16 \%$ in 1981 fell to $12 \%$ in 1988 . It then recovered to $15 \%$ reflecting the economic upturn but more particularly the abolition of the earning rule for state pensions under which pensions were reduced for people earnings above a given amount. The number of men aged 55 and over in the workforce fell from 3.2 million in 1971 to 2.1 million in 1991.

For women the position appears more stable (see Figure 2). The economic activity rate for women aged $55-64$ fell by only $12 \%$ between 1970 and 1985 but this is because the decline in older women's activity rates has been masked by the tendency for each succeeding generation (birth cohort) of women to have a higher activity rate than its predecessor. This is brought out in a comparison of the number of 55-59 year old women in 1984 with the number of those who were 50-54 in 1979. It shows a drop of 23\% (Casey and Wood, 1991). The number of women aged 55 and over in the labour force fell from 1.7 million in 1971 to 1.3 million in 1991, most of the fall being in the groups over 60 , the state pension age for women.

To sum-up, taking men and women together economic activity rates are estimated to have fallen between 1971 and 1991 from $71 \%$ to $67 \%$ at ages 55 to 59 , from $54 \%$ to $39 \%$ at $60-64$ and from $11 \%$ to $3 \%$ at 65 and over. The numbers in the workforce are estimated to have fallen from 2.3 million to 1.9 million at ages 55-59, from 1.7 million to 1.1 million at 60-64 and from 0.8 million to 0.5 million at 65 and over, a total fall of 1.4 million to 3.5 million. Before the 1980 recession older men were more concentrated in declining industries, but are not so now.

\section{Causes}

Growing unemployment tends to increase the numbers dropping out of the labour market because they become discouraged from looking for work. It is also associated with an increase in the number of older workers retiring from the labour market because of ill health. As labour market conditions deteriorate workers are more likely to accept the status of disabled (Piachaud, 1986) and doctors appear to be more likely to assess them as unfit for work. A serious feature of unemployment in the third age is that a high proportion is long-term. A quarter of all unemployment among both men and women aged 50-59 is over three years duration. Whilst short-term unemployment has an economic function in terms of labour mobility and keeping down inflation, long-term unemployment is a waste of resources, and is of course particularly devastating for the individual concerned. 
A number of factors affect the decision to leave paid employment. These include finances, health, compulsory retirement and redundancy. Research shows that the decision to retire and consequent satisfaction with retirement are both heavily influenced by financial circumstances. Individuals who are financially well prepared for retirement for example with the prospect of generous occupational pensions, are more likely to see retirement as an opportunity for leisure, travelling, hobbies, etc.

The numbers of retired people with retirement pensions has risen steadily over recent years from $34 \%$ in 1970 to $51 \%$ in 1985 (Dawson and Evans, 1987). (The OPCS 1988 survey found that of individuals aged 55 to $69,48 \%$ had rights to an occupational pension $(68 \%$ of men and $29 \%$ of women) and a further $11 \%$ had entitlements but had either cashed them or lost them in other ways.) Increased coverage by occupational pensions has been matched by an increase, in real terms, in their worth to those retiring. Moreover schemes have become more generous in their provision for early retirement, either because of ill health or redundancy. However it is important to point out that having an occupational pension does not automatically guarantee a comfortable retirement and does not necessarily remove the financial incentive to continue working. The main point to be made here is that the perceived adequacy of retirement income is likely to influence older people's interest in giving up work. Parker (1980) found that men who retired over pension age were less likely to receive an occupational pension than those who retired at pension age, suggesting that lack of income was a factor in their choosing to continue work.

The 1990 LFS shows that ill health and injury are major reasons for leaving employment among older people, and this is particularly the case among manual workers. About 1/5 men aged 55 to 64 who were not working in 1986 and who had left their jobs over the three previous years had done so because of injury or ill health (Casey and Laczko, 1989). Ill health was also the reason most frequently cited by women. Of the people aged 55 to 69 responding to the OPCS 1988 survey $37 \%$ of retired men and $29 \%$ of retired women gave their own ill-health as the main reason for taking early retirement. For about a third of these men and just over $10 \%$ of the women, subsidiary reasons include redundancy, retirement under a job release scheme or employees shedding staff of closing down. The health status of older men and women who are not working is much worse than the health of those who are working. Retirement on grounds of ill-health has tended to increase as the labour market has tightened.

Many employers in Britain operate a system of compulsory retirement corresponding to the state pension age. It is worth noting though that a European study shows that there is stronger objection to compulsory early retirement in the UK than in Europe generally (Timms, 1992). Of the respondents to the 1977 OPCS survey who retired at the state pension age, half of the men and 1/5 of the women were forced to retire (Parker, 1980).

The OPCS 1988 survey provides a different but broadly consistent analysis. It shows that of the retired respondents aged 55 to 69 retiring at state pension ages, $46 \%$ of men and $26 \%$ of women did so because it was the fixed age. For those who retired early, the proportion who gave employer compulsion or influence as the main reason for their doing so were $14 \%$ of men and $9 \%$ of women. This is less than the proportion giving as the main reason financial considerations ( $24 \%$ men and $8 \%$ women). When compulsory retirement does not coincide with an employees own wishes there is a feeling or resentment against being "thrown on the scrap heap". At present, however, there is no recourse to legislation to prevent their compulsory retirement on grounds of age unlike thcre is in the US. 
The process by which people below state retirement age move from full employment to economic inactivity is often via ill-health. The proportion of early retirers taking the sick or disabled route is about $50 \%$ (Trinder, 1989). Even though the numbers have increased dramatically in absolute terms the percentage has remained roughly constant at its present level for two decades. If individuals are asked why they retired early the most common reason given is ill-health. There is a continuing rise in the numbers claiming invalidity benefit and in the number of days of "certified incapacity". But the trend to earlier loss of employment is not due to an adverse trend in health. In the population generally, it appears rather that when the labour market is tight and jobs are being shed, ill-health becomes more significant and is more likely to be seen by workers and certifying doctors as grounds for early retirement.

The decline in employment in third age is partly the willing response of individuals to pension opportunities, particularly where the state pension is supplemented by occupational pensions. But much of the decline below the state pension age has been forced by labour market problems and constraints. These have been accelerated by the recession of the early and late 80 s but there has been a complex interaction between demographic, social and economic factors.

\section{International comparisons}

"Time for Retirement", a recently published study of trends in France, Germany, the Netherlands, Sweden and the UK (Kohli et al., 1991) make it possible to put the British changes in an international context. All the countries studied showed substantial decline in the proportion of third age men continuing in the labour force (the economic activity rate) and in the proportion of those employed (the employment rate). The long term trends began with a general decline in labour market participation of men of over 65 (from around $70 \%$ early in the century to around $20 \%$ in 1970 or about $25 \%$ in Sweden and the US). Since the 1960s there have been big declines in the activity rate of men aged 60-65 and smaller but substantial reductions in the rate for those aged 55-59. For women the picture is less clear-cut because as discussed above there has been a trend for the activity rate of successive cohorts of women to increase and this has masked the effect of the decline with age in the activity rate of each cohort. The net effect has been one of increases in the activity rate of the 55-59 group and reductions for the older groups.

Table 3 shows for each of the countries covered by the study labour economic activity rates in 1988 and the percentage decline since 1965 . It shows that the UK is in an intermediate position between on the one hand the three continental EC countries which have the highest rate of decline and on the other Sweden and the US, which for different reasons have the lowest. In France, Germany and the Netherlands, participation rate for the $65+$ group have declined by $75-84 \%$ to $3-5 \%$ of the age group; those for the $60-64$ group have fallen by $60-80 \%$ to $15-32 \%$; and those for the $55-59$ group have fallen by $15-31 \%$ to 60 $77 \%$. The biggest decline has been in the Netherlands and the lowest in Germany.

There is no simple explanation of the inter-country differences but in all of them the growth in the supply of labour exceeded the growth in the number of jobs and all have responded to some extent by reducing the activity levels of older workers. Macroeconomic factors have clearly been an important influence in the decline, shown for example in the way in which decline accelerated in response to the recessions of the mid $70 \mathrm{~s}$ and early $80 \mathrm{~s}$. There is, however, no simple correlation with economic performance or the economic cycle 
as is clear form comparison with Germany which over the period in question had higher average growth rates and lower unemployment, but a higher rate of decline in the participation of older workers which pre-dates the major recession of the mid $70 \mathrm{~s}$.

Table 3:

A. Economic activity rates 1988

\begin{tabular}{ll|r|r|r|r|r|r}
\hline & & France & Ger & Neth & Swe & UK & US \\
\hline Men & $55-59$ & 67 & 77 & 60 & 86 & 82 & 79 \\
& $60-64$ & 25 & 32 & 15 & 64 & 55 & 54 \\
& $65+$ & 5 & 5 & 3 & 19 & 8 & 16 \\
\multirow{4}{*}{ Women } & $55-59$ & 45 & 39 & 17 & 80 & 55 & 53 \\
& $60-64$ & 18 & 11 & 2 & 51 & 19 & 34 \\
& $65+$ & 2 & 2 & 0 & 5 & 3 & 7
\end{tabular}

B. Percentage change in economic activity rates $1965-88$

\begin{tabular}{ll|r|r|r|r|r|r}
\hline & & France & Ger & Neth & Swe & UK & US \\
\hline \multirow{2}{*}{ Men } & $55-59$ & 19 & 15 & 31 & 7 & 15 & 8 \\
& $60-64$ & 73 & 60 & 80 & 23 & 38 & 37 \\
& $65+$ & 84 & 80 & 75 & 50 & 67 & 40 \\
\multirow{4}{*}{ Women } & $55-59$ & 10 & 6 & -6 & 71 & 23 & 18 \\
& $60-64$ & -44 & -54 & -84 & 63 & -25 & -3 \\
& $65+$ & -74 & -72 & -82 & -58 & -55 & -21 \\
\hline
\end{tabular}

Source: Public Finance Foundation (1992)

What appears to have happened in the continental EC countries is that concern developed among the social partners (government, employers and unions) about the effects of structural changes in the labour market (on the demand side, pressures to reduce manning levels - mainly but not solely in declining industries - and on the supply side growing numbers of younger cohorts entering the labour market). This led to government action to facilitate early retirement as the most acceptable and practical way of dealing with the problems. New pathways to early retirement were created mainly using social security funds for unemployment and disability rather than pension funds (e.g. the French guaranteed income for dismissed workers over 60 , financed from the employment compensation fund, and the Netherlands introduced wider unemployability criteria in assessing eligibility for disability pensions). These led to an earlier and more substantial decline in activity rates than in the UK, where measures to facilitate early retirement were more limited and less generous (e.g. the job release scheme which ran until 1988 gave incentives only to the lowest paid; the higher level of income tested social security available to unemployed workers over 60 was at a lower level than the pension substitutes paid in continental Europe). Activity rates for men aged 55-64 had by 1985 fallen to $68 \%$ in the UK compared 
with $47-57 \%$ in the European countries. But since unemployment rates were higher in the UK there was a smaller differential in the proportion of workers in this age group actually employed ( $59 \%$ in the UK compared with $44-51 \%)$.

The country in the study with the lowest rate of decline in employment activity rates is Sweden where for men aged 55-64 activity rates had fallen to $73 \%$ in 1985 (13\% reduction) compared with $59 \%$ in the UK (a $32 \%$ reduction). For women of the same age there was an increase of $57 \%$. The main influence appears to have been a long standing policy of government intervention in the labour market to promote employment for older as well as younger workers. Publicly financed programmes have been used to influence labour demand (through public works, subsidised employment and sheltered work) and to influence labour supply (through training and mobility allowances). In addition action has been taken to reduce the number of hours worked by those in the labour force, including opportunities for partial retirement on a partial pension. Though successful in employment terms, these policies had high public expenditure costs, which contributed to the financial difficulties of the previous government (and probably to its defeat in the last election). It remains to be seen how far the policies will be maintained by the new government and what the effects of change will be.

The Swedish experience is likely to be of less interest to the UK government than that of the US which has adopted a policy of minimum intervention within a framework of protection for older workers' rights which prohibits discrimination and provides the payment of damages if it is proved. In common with Sweden and in contrast with continental countries there have been no public programmes for compensating older workers for loss of jobs or the ability to work but in contrast with Sweden there have been no positive public employment policies in favour of older workers (apart from a very few limited measures). As in the UK, individual companies have established private early retirement programmes where it suits company requirements. This is against a background of a highly decentralised labour market which appears to have been more successful in balancing labour supply and demand through reduction where necessary in real earnings. The outcome has been a rate of decline in the employment of older workers that is lower than in the UK though higher than in Sweden.

\section{Future projections}

In the 1990 s, in contrast with the last two decades, the population of working age is due to rise by only half a million. The numbers of "priıne age" females entering the labour force is expected to grow steadily, more than offsetting the much publicised decline in the numbers of young entrants. Most of the net additions to the labour force are expected to be women aged 25-54. Figure 3 and 4 show total employment is expected to increase by three quarters of a million, rather less than the increase in the labour force. This is made up of large increases in part-time work and self-employment (half a million and one and a quarter million respectively) and a large fall, nearly a million, in full-time jobs. If jobs increase at the same rate as in the 80 s (by 2 million including the self-employed and 1 million in employment alone), there will be scope for progress in reducing unemployment, or reducing forced withdrawal from the labour market of older workers and with continuing the increasing employment of women. But as usual it will not be possible to do all that is desirable and there will in effect be a conflict of priorities between these groups, the extent of which diminishes if economic performance is better than in the $1980 \mathrm{~s}$ and increases if it is 
Table 4:

Interest in employment amongst "third age" people not working, 1990

\begin{tabular}{l|rrr|rr}
\hline & \multicolumn{3}{|c|}{ Men } & \multicolumn{2}{c}{ Women } \\
& $55-59$ & $60-64$ & $65-69$ & $55-59$ & $60-64$ \\
\hline Would like work & 48.6 & 28.8 & 12.0 & 20.1 & 11.1 \\
Seeking work & 40.5 & 24.9 & 10.7 & 18.6 & 10.6 \\
Seeking p/t work & 6.4 & 9.3 & 8.1 & 13.3 & 8.9 \\
\hline
\end{tabular}

Source: Policy Studies Institute (1991), p. 53.

worse. In terms of demography alone the prospects for third agers who want to continue in work seem better than in the 80s but not to the extent assumed by those who have looked at the much publicised fall in the numbers between 16 and 34 ( -1.8 million) but have overlooked the rather larger increase in the 35-54 age group ( +1.9 million) and the continuing increase in women's activity rates. For older workers, whose numbers increase modestly ( 0.3 million compared with a 0.4 million reduction in the $80 \mathrm{~s})$, the prospects depend on the interaction between the overall growth in jobs, the effects of changes in industrial structures and occupational patterns and the preferences (where they can exercise them) of both workers and employers and the extent to which older workers can contribute to the skills needed in a growing economy.

All these changes have implications for older workers. Box 1 summarises prospects for older workers in the main industrial sectors. Women are expected to be the main beneficiaries of these changes, accounting for all of the net increase in employment. Self-employment has grown very rapidly in the last decade. In 1979 there were 2 million persons so classified. During the 1980 s over a million persons have been added to this category. It now accounts for over $12 \%$ of total employment and the increase of almost half a million forecast for 2000 will bring the proportion to 13.5 per cent. Self-employment status may, itself, assist individuals to remain economically active. Growing numbers of self-employed may therefore be good news for prospects of more jobs for older workers.

Simultaneous with the shift towards self-employment has been the move away from full-time employment. The 1980s saw a substantial loss of both male and female full-time jobs : female part-time jobs, on the other hand, grew rapidly. The majority of these jobs were in the service sector: around one third of all employees in non-marketed services, business and miscellaneous services, and distribution and transport were working part-time in 1990. In contrast, part-time employment in manufacturing has recently begun to decline. Continued changes in the industrial structure of employment in favour of services, coupled with growing proportions of part-timers in most of these industries, are expected to result in the forecast increase of over 1.25 million part-time jobs by the year 2000 compared with 1990. Most post-retirement age workers work part-time. The prospects for much more parttime work in the $1990 \mathrm{~s}$, therefore, also seem to offer greater job opportunities for the older worker.

To sum-up, some developments will favour third agers to some extent. First, there will be relatively high growth in service and information based industries. The particular qualities 
Box 1:

Prospects for older workers in the main industrial sectors

\section{Agriculture, forestry and fishing}

Employment in this sector as a whole is expected to continue falling. As a result the number of male older workers among managers and administrators (which includes proprietors), in this industry is expected to experience a slight decrease.

- Energy and water supply industries, manufacturing industries

Continued falling employment in these industries coupled with falling proportions of older workers is expected to lead to continuing losses, especially for older men. These are concentrated in craft and related occupations and amongst plant and machine operatives. Job losses for older women are also important in the "other manufacturing" sector (which includes textiles and clothing).

\section{Construction}

As a consequence of small increases in employment overall, the number of older males is projected to rise slightly in this industry.

- Distribution, transport and communication, etc.

Falling proportions of female older workers are projected to continue, coupled with a slight fall in total employment for women. This results in projected job losses for older workers in most occupations. The number of older males in sales occupation is also projected to fall.

\section{- Banking, insurance and finance}

The high and rising proportions of male older workers in the higher level occupations in this industry are reflected in the growth that is expected for these occupations. Many of these older workers include the tradition, as selfemployed professionals who tend to have longer working lives. In the case of women, however, it is the clerical and secretarial occupation which make up the main source of employment growth in this industry.

\section{Miscellaneous services}

Older workers in this sector are concentrated in higher level occupations and some growth in these occupations is expected. Female employment growth is expected to be concentrated in lower level occupations, such as personal and protective service and "other occupations".

\section{- Non-marketed services}

As in Miscellaneous Services, substantial employment growth is expected overall. Thus, despite a continuation of past trends which suggest declining proportions of those aged $55+$, the number of older workers employed in most occupations grows. 
of third age workers suit these occupations. Second, there is a continuing shift towards "non standard" jobs - casual, part-time and self employed. These jobs may well fit the kind of work pattern which many third agers prefer.

Moreover, while it is likely that the overall level of economic growth and the number of jobs available will greatly affect the opportunities open to older workers, this is not just a one way effect. It is also true that the more older workers that are available as part of the workforce, the higher the level of economic growth which can be sustained before skills shortages, local labour shortages and inflationary pressures emerge. Third age workers, especially if they have relevant skills and experience, can improve the prospects for the economy as a whole.

\section{Attitudes to retirement}

The main sources of recent statistical information about older workers attitudes and preferences are the Retirement Surveys carried out by OPCS in 1977 and 1988. Two other recent surveys have looked at olc' $r$ workers from professional and managerial occupations (IPM/KPMG, 1990; Webb and Townley, 1990). However these two surveys define "older workers" as those over the age of 40 years. In the Peat Marwick survey only $28 \%$ of all the sample were in the third age as defined by this inquiry and all were under 56 years of age. Half of Webb and Townley's sample were aged over 50 and $8 \%$ were over 60 . Nevertheless these studies do provide some useful insights which are relevant here.

Nine out of ten third age workers from the 1977 OPCS survey said that they would miss the money their jobs brought in if they had to give up working. Substantial numbers of third age workers also said that they would miss the people at work, the feeling of being useful, the work itself, things happening, and the respect of others if they had to give up their jobs (Parker, 1980).

When people who had passed the state pension age were asked why they continued to work, Parker found that although money was the main motivator, the decision to stay on was often based on a mixture of reasons including liking the work and wanting to avoid boredom, liking the companionship of fellow workers, and finding that work helped to keep one well and active (Parker, 1980). The 1988 OPCS survey gave similar results; the main reasons for postponing retirement were financial considerations and job satisfaction, with men giving more weight to the former and women to the latter (the main reason was financial for $51 \%$ of men and $44 \%$ of women, while the main reason was job satisfaction for $30 \%$ of men and $33 \%$ of women).

Similarly, on the IPM/KPMG survey of older managers and professionals (IPM/ KPMG, 1990) they found that the main motive for continuing work were salary $(57 \%)$ and friendship networks in the office $(27 \%)$, followed by benefits packages, status and intellectual challenge. Almost all had still had clear career aspirations and development needs. Webb and Townley's (1990) survey found that three quarters of older respondents still found their jobs challenging. The opportunities these high status employees experienced and continued to experience might well not be, nor ever have been, present for lower status employees whose perceptions might be very different.

The OPCS 1988 Retirement Survey asked older workers about the extent to which they felt satisfied with their jobs. Here a clear difference between those who were below retire- 
ment age and those who were above it was found. Thus, less than half of men 55-64 who were working found their jobs neither boring nor stressful, but three quarters of those aged 65 and over who were working did so. Similar results were obtained for women.

Studies have shown an interest amongst employees, both old and not so old, in opportunities for a more gradual withdrawal from work to retirement. Such gradual, or partial retirement offers the possibility of combining the benefits derived from work, such as enhanced income, personal challenge and social contact, with those frequently derived from retirement, such as enhanced leisure and being able to spend more time at home. In his analysis of the 1977 OPCS Retirement Survey, Parker found that the majority of third age workers would prefer a gradual retirement, with three quarters of all workers stating a preference for part-time work when they gave up their present job.

Most of the IPM/KPMG respondents wanted the option of a flexible decade of retirement, with early retirement between 51 and 60 , followed by periods of part-time or temporary work (IPM/KPMG, 1990). However, only $7.5 \%$ said that they had the opportunity of switching to part-time work in the period leading up to retirement and $13 \%$ said that their organisation encouraged part-time working after the normal retirement date.

Although most of the managers interviewed for the Industrial Society survey hoped to retire between the ages of 60 and 64 years, $85 \%$ said they would like some kind of part-time paid work after retirement. One reason for wanting to reduce working hours was the desire to improve the balance of time spent at home and at work: nearly twice as many respondents said that an improvement in the home/work balance would be an important factor in looking for their next job and had considered this when choosing their current post (Webb and Townley, 1990).

It seems difficult for many people, even if they want to and are prepared to accept less pay for it, to carry on doing their old job less intensively than before. In this respect, there are differences between different types of people in different situations. Some occupations, for example, senior professionals, executives and university teachers have established post career opportunities into which they could pass - consultancies, non-executive directorships, emeritus professorships. For others, the switch to lighter, or part-time work has been seen as a sign of failure or inability to cope and thus not contemplated; alternative forms of working have to become socially acceptable and as changes become widespread, particularly when they are not restricted to people in the third age, a "critical mass" of such working can be established.

Third age people have a wide variety of attitudes to their present jobs. They would have usually preferred to have stayed in their normal occupations rather than changed jobs where they have been occupationally downgraded. The attitude of third age people to reentering the labour market is that it is often impossible or difficult to move without severe occupational downgrading. If this could be avoided many more of those not economically active would be more likely to seek paid work. Occupational downgrading is not, however, always a negative phenomenon and at least some of the changes which occur at the end of working life might be desired by those who experienced them. It can mean something different for women than for men. For women, it is often the consequence of career interruptions and occurs in the "second" rather than the third age. This form of downgrading might become less important in the future as current cohorts of mothers are less likely to give up working and more likely to return to equal status positions. 
Retirement for some means increased leisure opportunities, a well deserved rest leading to improvements in health, time to spend with the family, the chance to do things they never had time to do and so on. However, for others retirement signals poverty, isolation, boredom and the beginning of "old age". It is important to point out that retirement can be voluntary or involuntary. That is, while some are able to make a positive choice to leave paid employment, others are forced to do so by compulsory retirement, redundancy or ill health. Individuals may be pressured into taking early retirement by their employers, or may retire early by default if they become unemployed and their job search is unsuccessful.

A sizeable minority of older people who are below state pension age and the majority of those above are not working. The non working group has grown during the last decade. But, non-working does not necessarily equate with having no interest in working.

The proportion of third age people who are not working and who in response to the Labour Force Survey, expressed an interest in taking up or returning to employment diminished as age increased. As can be seen from the Table 4, almost half of non-working men aged 55 to 59 in 1990 said they would like a job, of those aged 65 to 69 the proportion was only 1 in 8 . Older women who were working were less interested in employment than older men; at any age, the proportions of women claiming to want a job was less than half of that for men; those who had retired from their last jobs were less interested than those who had lost their last jobs. Of those actively seeking work in 1990, the large majority were seeking part-time jobs. Unemployed men below the age of 65 were the people who generally wanted full-time jobs.

According to the Gallup Survey of retired people the most common reasons for wanting to return to work were "liking to be with people" $(54 \%)$, and "money" $(36 \%)$. Women were more likely to miss both the money and the people when they left work.

Abolition of the earnings rule for pensioners, in 1989, was intended as an incentive for more older people to undertake some paid employment. Pension entitlements are no longer reduced for pensioners earning more than the specified limit (which was $\$ 75$ per week in 1989). The employment activity rate of men over 65 increased by 2 percentage points in that year suggesting that the change had only a limited effect on participation in paid employment among people over pension age, partly because the majority of those who are working earn substantially less than the earnings rule level, and partly because those who were high earners already had the option of deferring their occupational pensions, letting them appreciate for the duration of their employment.

Disincentives to taking paid employment still remain for those below pension age who are reliant on state benefits. Means tested benefits such as income support are reduced to take account of earnings and thus, people who can only earn small amounts of money from paid employment, such as those in part-time or casual jobs may find that any financial gains are wiped out by reductions in their benefit entitlement.

Thus the number returning to paid employment is small. Of those who do move from inactivity into work many do so via non standard jobs. Also case studies show that some people in the third age are prepared to aceept lower status jobs in order to return to employment. Many third agers have stated that they are prepared to invest in training for new occupations. Nearly two thirds of respondents who were interested in returning to paid employment in the Gallup survey of retired people over the age of 50 (CBI, 1989) said that they would be willing to undergo training in a new job. 
Once a special effort is made to recruit older workers, the numbers of older people expressing an interest in working rise dramatically. For instance the London Borough of Kingston recently ran a campaign against age discrimination, characterised by the slogan "teenagers aren't the only ones who shouldn't be judged by the colour of their hair". Monitoring of applicants in the periods before and after the campaign, showed a rise in the proportion of applicants who were over 50 from $16 \%$ before the campaign to $37 \%$ afterwards (Maclure, 1990, p. 17).

The general conlusion is that age discrimination and inflexibility of personnel and pensions policies are imposing work and retirement patterns on third agers which do not correspond to what many of them would prefer. Many of those who are classified as retired or sick would like to work and would look for it if they thought they had a reasonable chance of finding job. It is however impossible to calculate the extent of this concealed unemployment. Those who most need and want work for basic, financial reasons may be those least likely to get it because of lack of relevant skills and work experience in their second age; this applies particularly to men leaving early from declining industries, and to women with low level and interrupted work experience. Conversely those with skills and experience most important to employers and the economy may increasingly choose to retire early because of their secure financial situation.

\section{Policy options}

First, the third age labour market experience is crucially dependent on what happened in the individual's second age. Many elements of the perceived disparity between different groups of third age have their roots in the second age, and even in the first age and have to be tackled in a preventive fashion.

Second, the importance of taking account of the inevitable uncertainties that surround the issues raised. A few demographic features come clearly through the mists of the future but their importance depends on features that are still obscure. There are uncertainties for example about the rate of change in patterns of work and their implications for the third age - will there be extensive change to tele-working as the information technology visionaries expect or will change remain slow and gradual? There is great uncertainty among economists about the determinant of long-term trends in economic growth, the production function of neo classical theory, which relates output to the amount of capital and labour employed, has proved inadequate, explaining less than half of the observed differences, while the unexplained residual (labelled "technological innovation") is a poorly understood black box. More recent theory suggests that key factors are knowledge, ideas and skilled human resources capital, and it is seeking to tease out the relationships. It is uncertain how the theory will develop and more important how successful Britain will be in the practice or what the implications will be for the third age, which has an important contribution to make to knowledge and human resource capital.

Some forms of action seem likely to be beneficial whatever the outcomes (for example, eliminating inappropriate age-related stereotypes and criteria). Others, such as extension of mid-life counselling and training also seem likely to be beneficial but they need to be tested more widely and their application reviewed and revised in the light of experience. It seems right at this stage to maintain and develop opportunities for paid employment for people around or above present pension ages but it remains to be seen how successful these will be 
and it will be necessary periodically to take stock of the likely mix and balance between these and the leisure and voluntary activities discussed in other reports.

Third agers whose main employment comes to an end sooner than they want need help from employment agencies and other intermediaries (such as the Pre-Retirement Association) in making realistic assessment of their employment prospects as well as in finding employment opportunities. Box 2 lists a number of agencies. They reported that until the recession employers were becoming more aware of the case on business as well as socialeconomic grounds for meeting the demand from third agers to change or re-enter employment. Though the recession has reduced employers interest it was expected to re-emerge. The agencies' experience was that targeted marketing of older workers still needed to break through employers preconceptions and after ages 45-50 the effort was needed on a rising curve. The resources available for targeting older workers was limited as was the priority given to it in major business and official organisations such as CBI, BIM or DE was low. Except in the forces re-settlement network, longer range and preventative action tended to be under developed. The Pre-Retirement Association promoted courses in mid-life reassessment but, no doubt for cost reasons demand from employers was low.

Points of good practice in marketing the skills of older workers are that employers need to be approached on a business basis as too much stress on fairness can put employers off ; employers stereotypes of older workers need to be challenged on the basis of better information and a focus on older workers actual skills and qualities; accurate matching of skills

Box 2:

Agencies providing employment placement and advice to "third age" workers

- Age Resource/Age Concern

Age Works/ECC

British Institute of Management (Representation Office, London, and Career Development Service, Corby)

Brook Street

- Charity Recruitment Group

Department of Employment (Special Schemes, Sheffield)

- Forces Resettlement :

Tri-Services Resettlement Organisation

Officers Association

Regular Forces Employment Association

- Pre-Retirement Association

Succes After $60(60+)$ 
with job descriptions is essential; generalised advertising and well directed media publicity are valuable in catching the attention of employers and applicants: most value comes from building up networks which can establish reputation for continuity and reliability; applicants and volunteers can contribute to these networks, e.g. The Pre-Retirement Association operates on a cascade basis through local voluntary associations. The Retirement Trust, Future Perfect, and Re-Action and the Alliance Against Ageism are also involved in promoting the attributes of third age people. Agencies can help applicants to make the most of themselves by establishing realistic expectations, helping them to become aware of what they have to offer and how this corresponds to employers interests, both building up self confidence and cutting down exaggerated expectation; developing personal drive (" 30,40 or 100 applications may be needed but the job will come"); good presentation of track record, including advice on writing CVs and interview techniques (obvious points like focusing on performance rather than formal qualifications otherwise tend to be missed).

Several areas of concern and opportunities for development are the lack of resources to enable the agencies serving the general run of third agers to provide the same kind of service for people who need to change career as the Forces Resettlement Agencies do for retired service personnel; need for mid-life career planning, helping those who will need to change jobs to develop a saleable package of experience and training; opportunities for improving the placement of older workers through the introduction of individual records of achievement such as are proposed for service personnel.

In principle it is as objectionable to discriminate unfairly on grounds of age as it is on grounds of race or sex. There is however not the same consensus on age because it is widely regarded as a useful proxy indicator of whether people will have particular sets of qualities and it is therefore expedient for employers to use it as a screening device. Age is liable to be an unreliable proxy save at the extreme (and even there it is worth noting that Horowitz at 90 was better at the demanding activity of playing Beethoven than most prime age pianists). The "do nothing" option is not only unfair to individuals but unlikely to be in the best interests of employers. Completely to eliminate the use of age related criteria would be unrealistic but a reasonable option for employers might be to adopt and implement a code of practice on the lines of those suggested by the Institute of Personal Management (the key points of which are set out at Box 3). This entails a critical review by management of age related criteria in every aspect of employment decision making. It would allow such criteria to continue to be used where for example it was established that they constituted a reasonably good proxy measure of the qualities required and there was advantage to the organisation and potential applicants to have an indication of the age range in which successful candidates were likely to fall. Unnecessary and unfair arbitrary limits would, however, be eliminated.

A code practice of this kind might usefully be accompanied by a specific management objective to ensure that in practice age related criteria were rarely used and if necessary to set targets for reducing their use by adapting and extending the innovatory practices which a number of firms have adopted to utilise the strengths of older workers; the best publicised examples have been in retail services but there are opportunities in many fields including, for example, nursing, teaching, other caring work and information technology ; improving career management to avoid or reduce problems of career plateaus and skills obsolescence, including career counselling, appraisal assessment of training needs and planned movement inside and outside the organisation; measures to make it easier, for those who wish 
Box 3:

Recommendations for reducing age discrimination in employment

\section{Key suggestions}

The use of age and age related criteria should be challenged in every aspect of employment decision making, for example, in recruitment, selection for training, counselling, development, promotion; as a determinant of pay and as a criterion for redundancy.

Equal opportunities policies and practices should include a commitment to remove arbitrary age discrimination and promote the adoption of job related criteria for all employment decisions.

- All staff, particularly those making employment decisions, should be educated and trained about the business and human resource implications of age discrimination.

Dates of birth should be used only for monitoring purposes. Written statements to this effect should be made to gain the confidence of individuals and the commitment of staff making employment decisions on behalf of the organization.

- Monitoring should be carried out at regular intervals to find out whether or not there is any indication of unfair discrimination against particular age groups.

- Positive action policies should be considered to encourage individuals in age groups subject to disadvantage, particularly in relation to recruitment, training and career development.

- Age, age guidelines and age related criteria should not be used to exclude particular age groups.

and need to do so, to wind down or change career before state pension age; these include pre-retirement courses, counselling, out-placement and secondments. IBM skillbase is a potential model to follow in managing the transition from full-time work to leisure or part-time work, while BT has a manpower based equivalent for non-managerial staff ; developing new working term arrangements through job restructuring and sub-contracting, which can offer opportunities for older workers in self-employment and part-time work. There is a wide scope for action by national employer and management organisations including the CBI, TUC, British Institute of Management and the Institute of Personnel Management.

There are two basic reasons for government intervention in the employment of third age workers. The first arises where there are externalities, benefits to the public as a whole over and above those which can be expected from the operation of markets (including action to improve the working of the labour market). The second ground arises where there 
are issues of equity and social solidarity (the achievement of "a nation at ease with itself" in the Prime Minister's phrase). The two combine to justify government involvement in maintaining an overview and providing information to the public; policy on age discrimination; advisory and placement services for people in the third age who need to change careers.

It is essential for the Government to provide leadership and to ensure that the public sector acts as a good employer, and sets an example. The government, through the DE, needs to continue to develop its overview of third age employment and to publicise key findings for the benefit of employers and people in or approaching the third age. It will also be useful for government to bring together and where necessary supplement the information collected by employer and management organisations suggested above. Since employment and other issues overlap they would merit in having an agency, partly if not wholly financed by government, which would maintain an overview of the whole field. It might periodically repeat the snapshot and (directly or by commission work) fill in gaps in the available information.

There is a range of policy options on age discrimination which depend on how much government intervention is deemed necessary. They may be summarised as follow beginning with the least interventionist. The government might take the lead in producing a policy statement on the issues of principle which underlie age discrimination, explaining why age related criteria over a wide age range are so seldom justified and what the adverse consequences are. The key point to be brought out is that even where average abilities decline with age, as they do with manual strength, stamina and speed of reaction, there are wide variations around the average (reflecting individual characteristics as well as factors such as experience, training and life style), so that the differences within age groups are often as great as those between age groups. Age is therefore at best an indicator at least up to 70 or 75 and is never a good basis for automatic decision on employment issues. For the same reasons it is an unreliable basis of screening, which can result in decisions that are inefficient for the organisation and unjust for the individual.

A statement on discrimination might be incorporated in a consultative document. It would sum up the progress made and promote discussion of the ways forward. It might include a readiness to consider legislation if adequate progress was not made through voluntary action in improving employment prospects of older workers and eliminating discrimination. The experience of legislation on sex and race discrimination suggests that legislation could not be ruled out $a b$ initio on grounds of feasibility. The government would need to consider in the light of progress made by voluntary action by employers whether the scale and seriousness of outstanding problems justified the cost of legislation to government and to employers. Accepting in principle the possibility of legislation might provide a stimulus to a voluntary action.

Government would need to monitor trends in employment of third age workers, trends in human resource policies and evidence of hardship accumulated by the organisations who argue for legislation. It might undertake surveys to identify any trends in the numbers of people reporting hardship and serious dissatisfaction as a result of forced withdrawal from employment. In 1992 the Government, following a Manifesto commitment, set up a new Advisory Group to identify and encourage examples of good practice in the employment of older people. This could be used to also monitor progress. 
The Equal Opportunities Commission (EOC) or some new body with responsibility to investigate and report on age discrimination might be given a remit to investigate reported cases of age discrimination, to seek resolution by voluntary action and to report to Government in the light of experience in other fields on the extent and seriousness of discrimination and desirability and feasibility of legislation. This could be complementary to other options, and it could be for a defined experimental period with possibility of renewal or withouth time limits. It would carry additional costs for government and employers who would be involved in providing information about and discussion of cases reported to the commission.

There are various options for legislating against age discrimination within defined limits. These include legislation targeted on specific problems, e.g. discrimination in recruitment, use of upper age limits in advertisements (following the example set by France and Germany); legislation limited to people up to defined ages (for example the US Age Discrimination in Employment Legislation which initially in 1967 allowed compulsory retirement at age 65 , a limit was raised in 1978 to age 70 ); it would seem sensible to ban age discrimination in recruitment, training and promotion up to an earlier age than compulsory retirement, e.g. 65 for the former and 70 for the latter ; limited through provision for exceptions to be allowed in defined circumstances - these might extend for example to cases of redundancy where at a time and place of high unemployment employers and workers agreed that the socially equitable course was to select employers over a given age (there could be variants as to what degree of support from workers was required and how it should be expressed and as to whether the rules should be subject to consideration of cases of special hardship).

There is already access to employment tribunals for appeal against unfair dismissal before retirement age and they have taken the line in some cases that dismissal is unfair where it is based on a policy of protecting younger workers. There are options of reinforcing this type of decision by clarifying amendments (for example to the effect that reliance on age related criteria without considering the circumstances of the individual constituted on fair dismissal); there are also options for extending employment protection from state or company pension age to say 70 and/or extending employment protection to part-time and casual workers.

The only developed western nations to have detailed national legislation covering age discrimination in most aspects of employment are Canada and the United States. The Netherlands has also introduced a provision in its constitution which forbids age discrimination. One of the state governments in Australia has also introduced legislation against age discrimination in employment. South Australia also amended its Equal Opportunity ACF in 1991 to outlaw age discrimination in the areas of employment, position of goods and services, accommodation, education and clubs and associations. The provisions on employment will come into full effect in 1993. In addition other countries such as France and Germany have more limited prohibitions on ageism in employment. (Drury [1990]; Tillsley [1990]).

Because the main problems are for those with poor second age training and work experience who find themselves unemployable in their $50 \mathrm{~s}$, the case for legislation against age discrimination in recruitment, training and promotion is seen as stronger than that against age discrimination in retirement and redundancy. (Such legislation might apply not just to 
employers but also to government training programmes). There is however also a case for barring age discrimination in retirement and redundancy, thus forcing the employer to look at the circumstances of the individual.

The experience of employment agencies and other intermediary bodies suggests that a valuable option would be additional resources for services providing career guidance and help with job-searching to third age people who need to think through a change of direction in their lives either because they are approaching retirement age or because they face prospects of early retirement. A few organisations notably the Armed Forces are able to provide high quality services but the benefit to an organisation from such activity may be small and it will be often be squeezed out by cost pressures. Such services are an essential complement to training and there are grounds for government support from the points of view both of society and economic externalities. Support might be channelled through Training and Enterprise Council and the service provided directly by the employment service or under contract by independent agencies. Expansion might be on a pragmatic experimental basis with careful monitoring of results.

\section{Conclusions}

It is clear from the research evidence that many people have lost out in the third age through factors over which they have no control, for example from the decline of industries to which they gave their working lives or the results of inadequate education and skill training. There are, however, things that people can do as they come up to and go through the third age which can help them make the best of the hands they are dealt. These include periodically taking stock of the problems and opportunities of the third age and how they can best respond to them, including understanding the risks of the third age - the possibilities of early retirement, the risks of boredom and frustration, the risks that occupational and personal pensions will not keep pace with inflation and the probability that the state pension will fall in relative value by comparison with earnings of people in work, even though it continues to be inflation-proofed; taking opportunities for mid-life career counselling, training and changes in work experience; looking out for opportunities for selfemployment and part-time employment as retirement approaches; finding out about the sources of information about employment opportunities in the third age ; joining unions and voluntary associations which represent the interests of older workers and can provide help and advice.

Ageist attitudes towards older workers mean that there are now thousands of experienced older people unable to get jobs. Discrimination can be found in every type of workplace and can happen at every stage-from the recruitment process and job advertissements right through to on-the-job training and promotion prospects. Employers need to have policies on older workers and to perceive age discrimination as an equal opportunities issue. This means that age should not be unfairly used in the employment process.

With a little imagination the labour market might be got to work better in everybody's interest, and government and the many employers who recognise wider responsibilities to the community might further improve the prospects of those approaching retirement, especially the disadvantaged. It must, however, be recognised that change will be difficult, and that there will sometimes be conflicts of interest, between the employer and individuals, and between individuals of different ages. These conflicts are heightened at times of 
recession and in areas of high structural unemployment. In the longer term regional, educational and other policies might ease these problems for people in the second as well as the third age. What this paper seeks to suggest is an approach which reduces discrimination and opens up opportunities for older workers, whilst taking proper account of the valid shortterm interests of employers and of younger workers. 
Figure 1:

Estimated employment - population ratio for 50-74 year old males in five year bands in the United Kingdom, 1973-90, with forecasts to to 1992

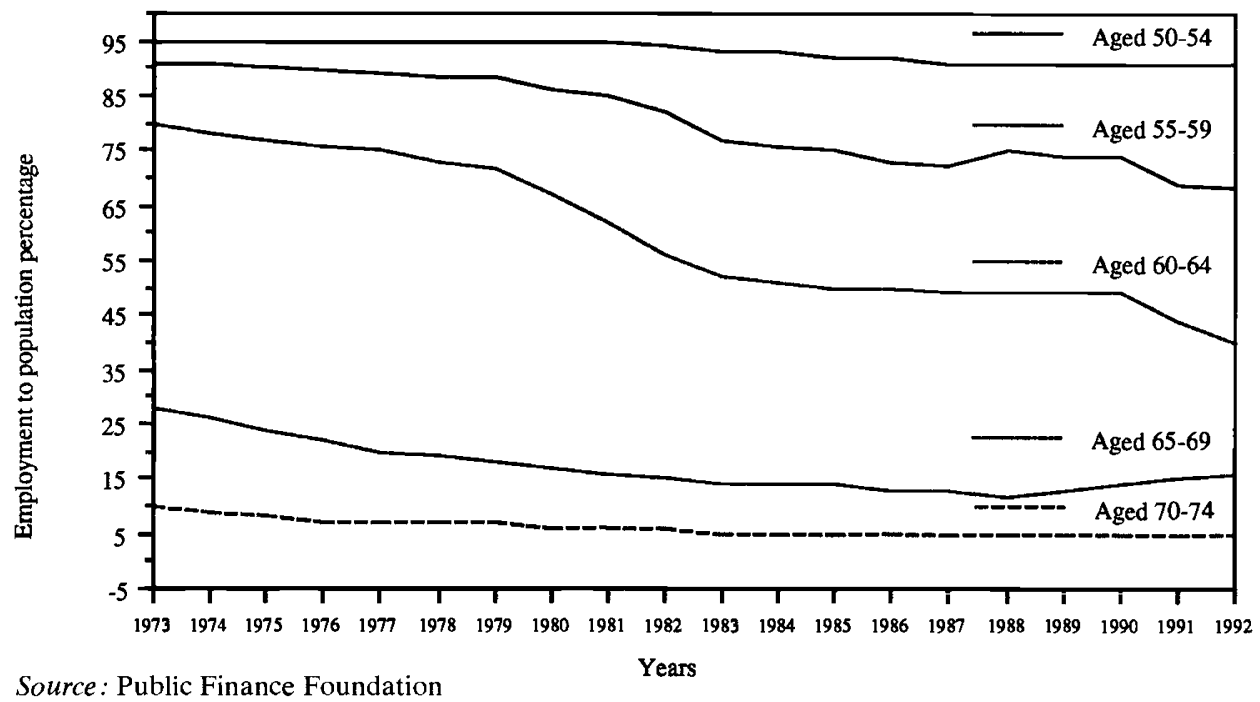

Figure 2:

Estimated employment - population ratio for 50-74 year old females in five year bands in the United Kingdom, 1973-90, with forecasts to 1992

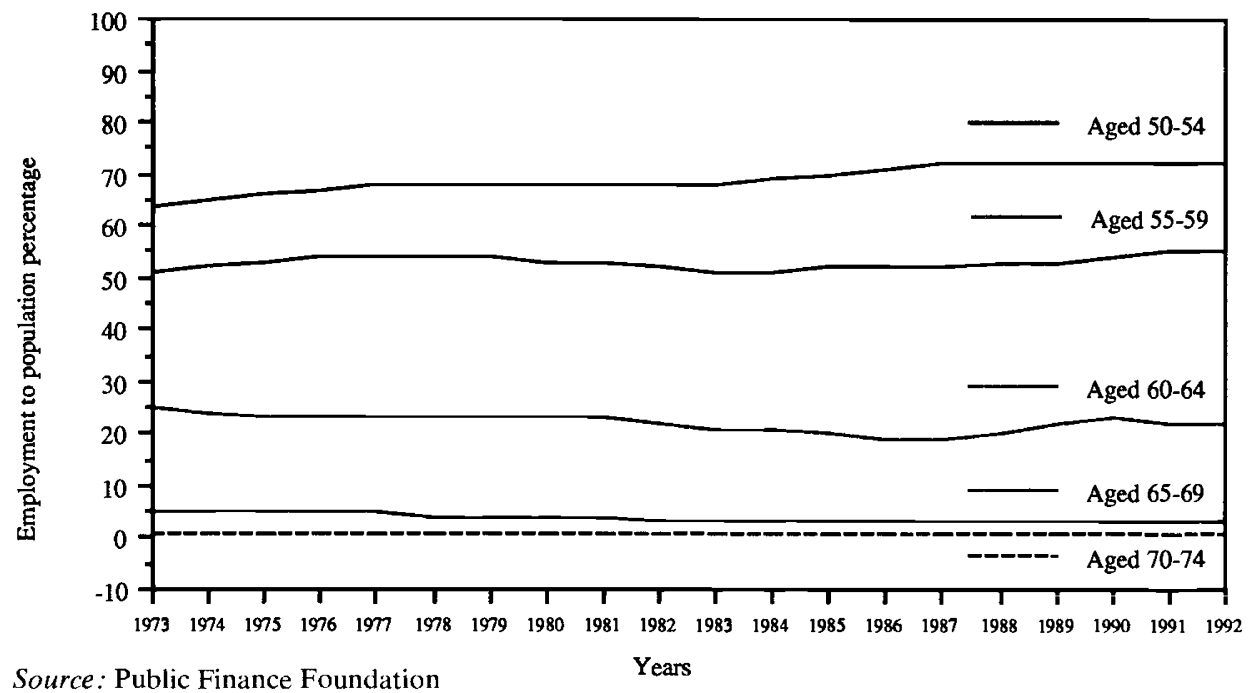



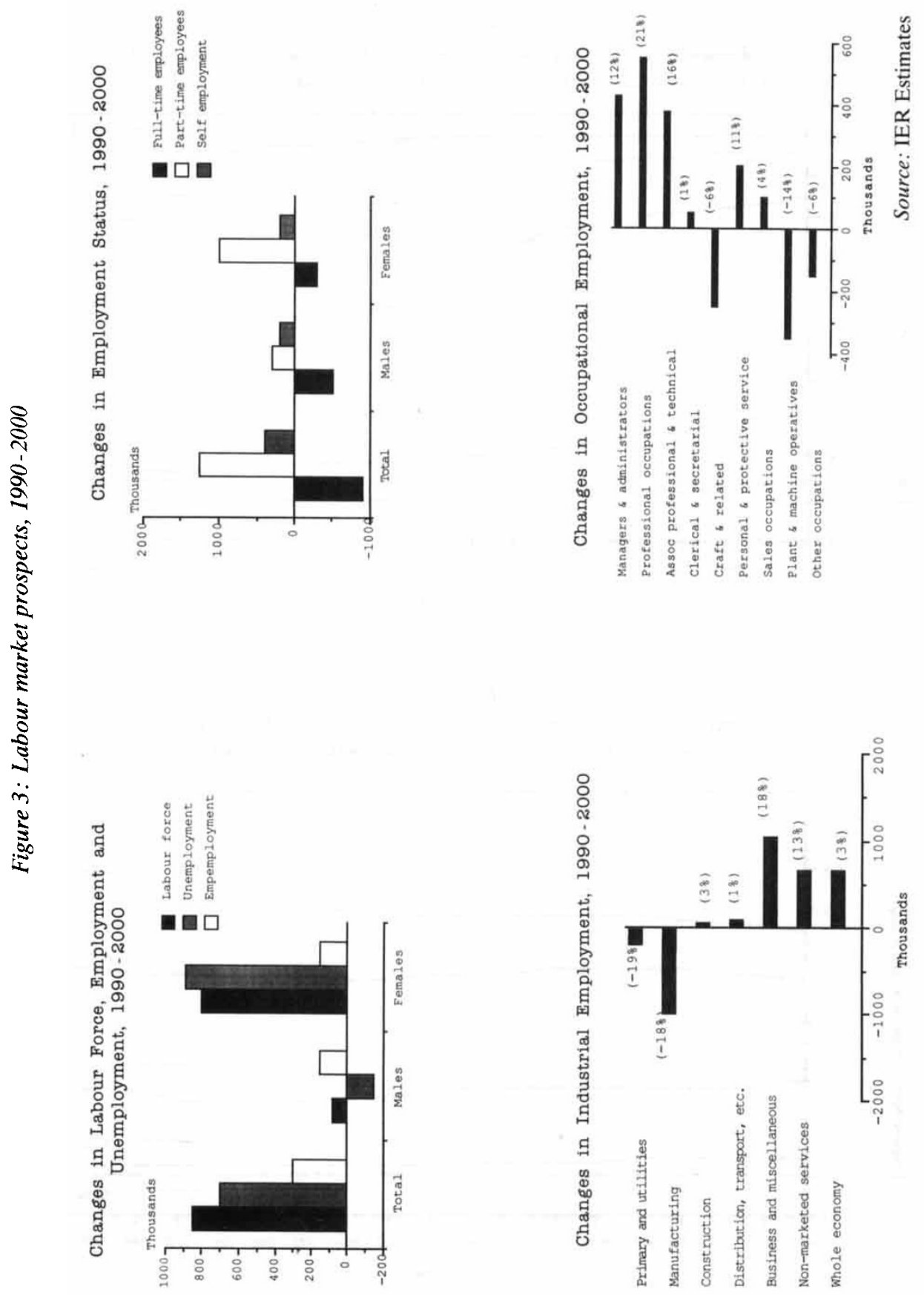
Figure 4: Population and labour force projections, $1990-2000$

Projected Changes in Population (000s)

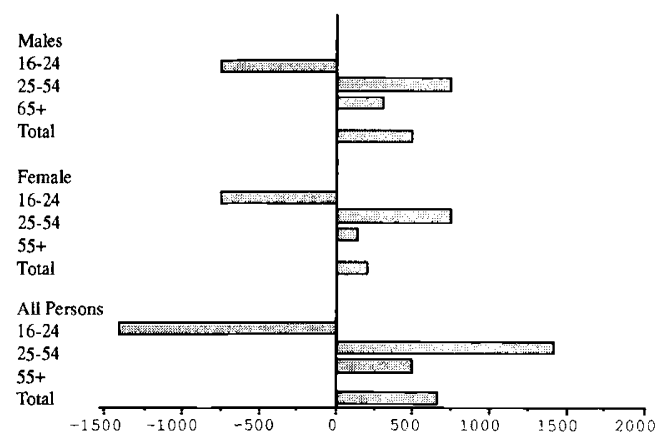

Projected Change in Labour Force (IER) (000s)

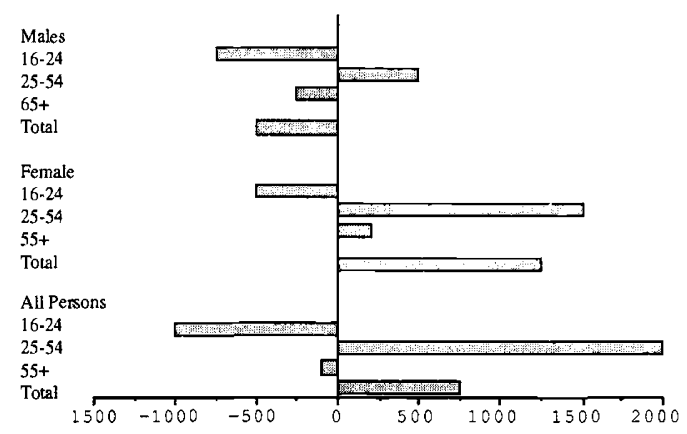

Projected Change in Labour Force (D.E.) (OOOs)

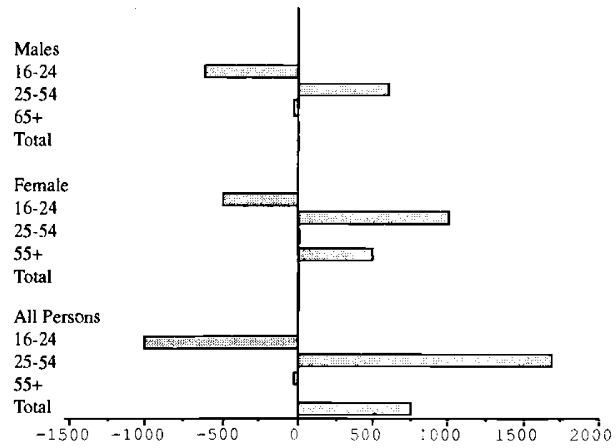




\section{REFERENCES}

CASEY, B. and LACZKO, F., (1989), "Early retired or long-term unemployed: The situation of nonworking men aged 55-64 from 1979 to 1986". Work, Employment and Society, Vol. 3, Issue 4.

CASEY, B. and WOOD, S., (1990), "Firm policy, state policy and the recruitment and retention of older workers in Britain". Policy Studies Institute Conference Paper.

CBI, (1989), Workforce 2000: an agenda for action.

DAWSON, A. and EVANS, G., (1987), "Pensioners incomes and expenditure 1970-85". Employment Gazette, May.

DRURY, E., (1990), Age Discrimination - European Community Perspective, Eurolink Age, Bulletin, November.

Equal Opportunities Review, (1989), Age Discrimination: Over the hill at 45. EOR, No. 25, May/June.

Future Perfect, (1991), Third Age Issues Study: The management and employment of people aged 45 plus, London: Future Perfect.

Institute of Personnel Management, (1991), Age and Employment: An IPM Statement. IPM, London.

KOHLI, M., REIN, M., GUILLEREND, A. and van GUNSTEREN, H., (eds.) (1991), Time for retirement: Comparative studies of early exit from the labour force, Cambridge University Press.

Labour Force Survey, (1990), London, HMSO.

MACLURE, C., (1990), "Old age misconceptions". Local Government Chronicle, 3 August.

OECD, (1986), Labour Force Statistics, OECD, Paris.

OPCS, (1977), Retirement Survey, London, HMSO.

OPCS, (1990), Retirement Survey, London, HMSO.

PARKER, S.R., (1980), "Settling for roses round the door: The experience of early retirement". Employment Gazette, December, 1216-8.

PIACHAUD, D., (1986), Disability, Retirement and Unemployment of Older Men. Journal of Social Policy, Vol. 15, para 2, April.

TILLSLEY, C., (1990), The impact of age on employment, Warwick Papers in Industrial Relations, No. 33, IRRU, University of Warwick, Coventry.

TIMMS, N., (1992), Family and Citizenship: Values in Contemporary Britain, Dartmouth: Aldershot.

TRINDER, C., (1989), Employment over 55, National Institute of Economic and Social Research Discussion Paper 166, NIESR, London.

TRINDER, C., (1991), "Older Workers and the Recession", Employment Institute Economic Report, Vol. 6, No. 2.

TRINDER, C., HULME, G. and McCARTHY, U., (1992), Employment: The Role of Work in the Third Age, Carnegie Inquiry into the Third Age Research Paper Number 1, ISBN 0900259205. Centurion Press Ltd., 52 George Street, London W1H 5RF.

WEBB, S. and TOWNLEY, A., (1990), Valuing Maturity. A report on the employment of mature managers. The Industrial Society, London.

WELLS, B., (1989), "The labour market for young and older workers". Employment Gazette, June $1989,319-331$. 